\title{
Social Media for Organic Products Promotion
}

\author{
M. Pechrová ${ }^{1}$, V. Lohr², Z. Havlíček ${ }^{2}$
}

${ }^{1}$ Department of Economics, ${ }^{2}$ Department of Information Technologies, Faculty of Economics and Management, Czech University of Life Sciences Prague, Czech Republic

\begin{abstract}
Anotace
Cílem článku je představit nová sociální média jako jeden z efektivních marketingových nástrojů pro ekologicky hospodařící zemědělce. Výzkum zahrnuje aplikaci praktických doporučení navržených Lohrem (2013). Pro jejich ověření na úspěšně zavedené koncepci pracující s přesně definovanou cílovou skupinou byla zvolena data z Facebooku Provozně ekonomické fakulty České zemědělské univerzity v Praze. Jako jeden z klíčových indikátorů úspěchu je zkoumán dosah publikovaných př́ispěvků. Pro jeho zvýšení doporučujeme publikovat kratší př́ispěvky a zábavný obsah (jako jsou fotky). Zvlášt' analyzujeme vliv her a soutěží na loajalitu fanoušků a doporučujeme jejich využívání pro lepší kontakt s uživateli.

Výsledky souběžně provedené studie využití Facebooku k propagaci bioproduktů ukázaly, že mít mnoho fanoušků na stránkách Facebooku nutně neznamená, že budou také aktivní. Distribuce aktivit odpovídá tzv. „dlouhému chvostu“, čímž s využitím teorie sociální výměny podle Emersona (2003) implikujeme, že potenciál sociálních médií farmářských stránek je v dnešní době stále vysoký a na své využití teprve čeká. Sociální média mohou složit farmářům jako marketingový nástroj, ale zatím nejsou plně využívána. Jedním $\mathrm{z}$ důvodů může být neobeznámenost zemědělců s možnostmi, které se nabízí, nebo nezkušenost s novým druhem nástroje
\end{abstract}

\section{Klíčová slova}

Sociální média, výrobkový marketing, bio produkty, Facebook, příspěvek.

\begin{abstract}
The aim of the article is to introduce new social media as one of effective marketing tools for organic farmers. The research includes an application of recommendations proposed by Lohr (2013). In order to verify them on successfully implemented concept working with precisely defined target group the data from Facebook of the Faculty of Economics and Management of the Czech University of Life Sciences Prague were chosen. As one of the key indicators of success the reach of the published posts is examined. For its increasing we recommend to publish short posts and amusing content (such as photos). We analyse separately the influence of games and competitions on the loyalty of fans and recommend using them for better communication with users.

The results of mutually done analysis of utilization of Facebook to promote organic products showed that having a lot of fans at Facebook does not necessary mean that they are active as well. The distribution of activities corresponds to the so-called "long tail", which implies, using the theory of social capital exchange according to Emerson (2003) that the potential of social media for farmers' pages is nowadays still high and still waits for its utilization. Social media can serve to farmers as a marketing tool, but are not fully utilized yet. One reason might be that farmers are not familiar with possibilities or lack of experiences with this new tool.
\end{abstract}

\section{Key words}

Social media, product marketing, organic products, Facebook, post.

\section{Introduction}

Social media refers to the interactions among people in which they create, share, and/or exchange information and ideas utilising social exchange theory (see Emerson, 2003) in virtual communities 
and networks such as Facebook, Twitter, LinkedIn, Instagram, etc. Social Media environment is still changing and social networks vary in the presentation of advertisements and information. "Social media is changing the business landscape and redefining how businesses communicate across their channels of distribution and with their customers." (Rapp et al., 2013)

A new form of communication with customers which enabled to serves the niches has emerged. The fact that the internet enabled selling to wider range of demanders led Anderson (2006) to develop the theory of "Long tail". He defines it as the ,end of the demand curve“. According to it the development resulted in the "fragmentation" of the market and wider choice of the customer. The ability to serve small markets or decentralized customers is one of the advantages of social media. According to Červenková et al. (2011) "Social media have become an integral part of marketing strategies and cost structures of many companies all over the world."

Organic products had the characteristics of the niche. However, "there has been a general increase in demand for 'organic' or 'biodynamic' produce (Jensen and Baggesen, 2014). It resulted to the situation described by Sage and Goldberger (2014). "Over time, if this niche proves profitable, it will attract more producers, thereby changing the face of the niche from a potential monopoly toward a competitive market" (Sage and Goldberger, (2014). The organic producers face increasing competition on the market. Because of the "Long tail" theory, social media can serve as a powerful marketing tool to organic farmers to promote their products.

However, social media considerably differ from other media. "They are rather resemble dynamic, interconnected, egalitarian and interactive organisms beyond the control of any organization (Peters et al., 2013). Their administration is in many cases beyond the current experiences of companies' management. Farmers are not familiar with possibilities which are provided and if so, it is too far from their daily routine. Also the research of Sturiale and Scuderi (2013) highlighted "the need for new managerial capacities: on one side that of creating consistent contexts that users appreciate and may well integrate the offer; on the other side that of managing the evolution of knowledge and competence systems deriving from external sources." Therefore, the aim of our research is to present and verify the suggestions how the Facebook can be utilized as a marketing tool for organic farmers.

\section{Facebook as a marketing tool}

"Facebook is a service on which users can find and add friends and contacts, send messages to friends, and update personal profiles. However, social networks are a qualitatively different type of product than text, pictures, and videos; there is a shift from the individual to the collective, as social networks leverage the power of relationships and the collective wisdom of man." (Berthon, 2012) There are around 1.3 billion Facebook users and 54.2 million Facebook pages created. The number of users is still increasing, e.g. between 2002 and 2013 increased by $22 \%$. In 2010, companies spent about $\$ 62$ billion on advertisements on social network sites (Gregurec, et al., 2011), which shows the growing importance of social media as a marketing channel (Hofmann et al., 2013).

Among the key indicators of success in social media presentation belong number of users involved in communication and total reach of published contributions. Peters et al. (2013) suggested nine guidelines in their study that may prove valuable for designing appropriate social media metrics and constructing a sensible social media dashboard. In Facebook environment number of shares, likes and comments are usually observed.

Social media communication, also known as usergenerated, "now represents a prevalent source of information; it has changed the tools and strategies companies use to communicate, highlighting that information control now lies with the customer." (Michaelidou et al., 2011)

The communication between organic farmer and customer should be elaborated at three levels (Sturiale and Scuderi, 2013): (1) connection: build up trustworthy relations besides the mere possibility to find out market niches or communities to develop products and services; (2) conversation: provide tools and interaction models to create a shared "sense" that goes behind the brand name, that allows companies to enter their market of reference; (3) construction: offer consumers platforms and structures to develop products with members' contributions.

Erdogmus and Cicek (2012) proposed several tactics for the practitioners, how to create content at Facebook pages to build brand loyalty. The results show that that the company should offer advantageous campaigns, relevant and popular contents. Besides, this content 
should appear on various platforms and offers applications on social media. (Erdogmus, Cicek, 2012) Interestingly, customers prefer to share music, technological-related, and funny contents on social media platforms. This finding are in line with the recommendations of the "Social Media in Business" (SMIB) methodology proposed by Lohr (2013).

\section{Materials and methods}

The aim of the paper is to introduce new social media as one of effective marketing tools for organic farmers applying recommendations proposed by Lohr (2013) in his so-called SMIB (social media in business) methodology. The guidelines for organic armers are given how to utilize the social media, particularly Facebook, as a marketing tool. The question is how to build effective communication with customers and other stakeholders which would help to promote the products of organic farming.

Analyzed sample is firstly described in terms of the structure and activity of the users and then following statements are explored:

1. Text of the messages for publication in social media is suitable to create short.

2. The company should utilize amusing and creative approaches in social media to better achieve set objectives.

3. The company should utilize applications, games or other elements of virtual reality to increase the involvement of their fans.

For verification of the first statement a Pearson correlation coefficient and ordered multinomial regression model (supposing logistic distribution of the error term) was estimated by maximum likelihood. As explained variable $\left(y_{i}\right)$ was chosen the category of reach: 1 - 0 to 2000 reached users (there were 83 cases in this category), 2 - 2001 to 4000 reached (there was 146 posts in this interval), 3 - over 4001 reached people (136 posts). Explanatory variables were related to the posts' type. Testing several variables revealed that only two of them were statistically significant: $x_{1 i}$ - the length of the post (number of characters including the spaces) and $x_{2 i}$ and $x_{3 i}$ - day when it was posted (dummy variable taking the value of 1 if the status was published on Saturday or Sunday and value of 0 otherwise).

Logistic regression examines the log-odds (a ratio of expected number of successes to each failure) (1). Its interpretation is in terms of the odds ratio
(OR). It measure the odds that the category of reach will be higher than the basic one ( 0 to 2000 reached users) given the length of the post and time.

$\ln \left(\frac{p\left(y_{i} \mid \mathbf{x}_{i}\right)}{1-p\left(y_{i} \mid \mathbf{x}_{, i}\right)}\right)=\beta_{0}+\mathbf{x}_{i}^{T} \boldsymbol{\beta}$,

where $p$ is the probability and $x_{i t}$ is a matrix of $k(k=1, \ldots 3)$ explanatory variables. To incorporate unobserved heterogeneity into a model a farm-specific parameter is added. This $\beta_{0 i}$ constant can be treated as fixed $\left(y_{i t}\right.$ is assumed to be independent) or random ( $y_{i t}$ is assumed to be conditionally independent given $\beta_{0 i}$ ).

The second statement is related to the post content. We analysed what type of publication (text / photo / link / share or video) had the highest reach. Further examination considered the optimal number of posts per time period in order to achieve high reach.

The third statement was verified on the game - Christmas competition held on FEM Facebook in December 2014. The loyalty of the users to the game was examined.

In order to verify the SMIB recommendations on successfully implemented conception working with precisely defined target group the data from Facebook of the Faculty of Economics and Management of the Czech University of Life Sciences Prague were chosen. We observed them for time period 1-11/2013. We omitted the values from December as there was a change in methodology of reach calculation in December 2013.

The statistics about the number of posts (in general any published text/photo/video/share of the post published at Facebook timeline page), fans (Facebook users which marked the page as "Like") and activity (any comment to the post or share of the post, or any "Like" of the post) were gathered. The dataset is sufficiently large as there is regular activity on the Facebook page (https://www.facebook.com/pef.czu.cz).

There are around 15 thousand students registered at the university, hence, there is quite high number of fans -7392 as of 23 December 2013. Fans of Facebook pages consist of $62 \%$ of women and $38 \%$ of men. This is opposite to the structure of the whole Facebook, which is used by $46 \%$ of women and $54 \%$ of men. Not surprisingly, the majority of active users is between 18-24 years old (41\% women, $25 \%$ men) and between 25-34 years, which corresponds to the students' 
age structure.

The activity of users on FEM Facebook sites has the long tail distribution - i. e. small number of users creates the majority of activities, while the majority of users are active only rarely or not at all. From the total number of fans only 1587 $(21.47 \%)$ were active. Active in this case mean that the user ever wrote any comment or "liked" any post or picture of the faculty page. In total those 1587 fans performed 4051 activities. This suggests that on average one active fan has made 2.55 activities. However, the distribution is different - 1975 users performed only 1 activity, while the majority of activities (over twenty) were done by 16 people. In other words only $1 \%$ of people create $20 \%$ of activities. The median of activity is ensured by 204 people. Among the five most active people belong also 3 page's administrators. Regarding the gender structure, active users slightly differs from the fans of the Facebook page - all men are active, while the percentage of women is lower.

An analysis of utilization of the Facebook to promote organic products in the Czech Republic is done next. The Facebook pages were reviewed on 23rd December 2013 according to the keywords related to the organic farming:

- farmářské trhy - farmers' market,

- bioprodukty - bio products,

- ekologické zemědělství - organic farming,

- biopotraviny - organic products.

As it will be shown, the dataset is still not sufficiently wide and hence the possibilities of the Facebook are not yet exploited.

\section{Results and discussion}

Firstly, three recommendations of SMIB methodology are verified.

\section{Text of the messages for publication in social media should be short}

The shortest post (excluding 4 photos with no post at all) was photo "Léto 2013" with 9 characters. The longest information about transport situation near the university during floods situation contained 1083 characters. Informational posts naturally contain more characters than mere comments to the photo. We analyzed the relation between the post length and reach. However, there was no correlation found between the length of the post and post reach. Pearson correlation coefficient was almost zero (-0.0125) and statistically insignificant $(\mathrm{p}=0.812)$. The relation between number of "like" of the posts of FEM CULS pages between 09/2011 and 06/2013 and the post length was examined already by Lohr (2013). He supposed that at the long messages the reader looses attention and the level of their interest decreases with the length of the message. He proved this by a linear function with slightly negative slope. The longer was the post, the lower number of likes it received. We had different data - for period of $01 / 2013$ to $11 / 2013$ and therefore the results are different. The slope coefficient is positive. The relation expressed by linear function (post reach $=3115+1.2785$ post length) shows that the longer is the post, the higher is the reach.

This calls for detailed examination and taking into account also other factors. Original logistic regression model contained following explanatory variables: hour and minute of the post publication, dummy variable for a day in a week, dummy for AM / PM, dummy for exclamation mark contained in the status and question mark contained in a status and the number of posts' characters. However, only post length $\left(x_{1}\right)$ and Saturday $\left(x_{2}\right)$ and Sunday $\left(x_{3}\right)$ turned up to be statistically significant (see Table 1).

The explanatory power of the model is relatively high (in $40.5 \%$ cases the model correctly categorize into reach category based on the fact, if the post was published on Saturday or Sunday and had particular length). LR test follows the chi-square distribution with degrees of freedom equal to the number of regressors. If the null hypothesis is true, the chances of obtaining a chi-square value of as much as 48.6125 or grater is practically zero. This suggests that collectively all regressors have strong influence on the probability that the post will fall into particular category of reach.

The coefficients are ordered log-odds (i.e. logit). If the post length is increased by one character, the log-odds of being in a higher category of reach (in comparison to the base interval from 0 - 2000) increases by 0.0012 . The odds interpretation of the coefficients is as follows: When the post is published on Saturday, the odd in favour to reach higher number of users decreases. On the other hand, if it is published on Sunday, the odds in favour to reach more users increase.

Logit model confirmed the results from the correlation analysis. The odds of higher reach mildly increase if the status is longer. This finding is not in line with our expectations. We supposed that during longer reading, the reader might lose attention. For example Yoshimura (2006) 
Likelihood ratio (LR) test: Chi-square(3) $=48.6125$

\begin{tabular}{|c|c|c|c|c|c|c|}
\hline Variable & $\begin{array}{l}\text { Coefficient } \\
\text { (log-odds) }\end{array}$ & Std. error & Z-value & P-value & $\mathrm{P}>|\mathrm{z}|$ & $\begin{array}{c}\text { Coeffient } \\
\text { (odds) }\end{array}$ \\
\hline$x_{1}-$ post length & 0.0012 & 0.0007 & 1.8110 & 0.0701 & $*$ & 1.0012 \\
\hline$x_{2}-$ Saturday & -0.5518 & 0.2685 & -2.0550 & 0.0398 & $* *$ & 0.5759 \\
\hline$x_{3}-$ Sunday & 0.6135 & 0.3517 & 1.7440 & 0.0811 & $*$ & 1.8469 \\
\hline cut1 & -0.9970 & 0.2032 & -4.9070 & $9.24 \mathrm{e}-07$ & $* * *$ & \\
\hline cut 2 & 0.7987 & 0.1994 & 4.0060 & $6.17 \mathrm{e}-05$ & $* * *$ & \\
\hline \multicolumn{2}{|l|}{ Log likelihood } & -383.2103 & & \multicolumn{2}{|c|}{ Akaike criterion } & 776.4206 \\
\hline \multicolumn{2}{|l|}{ Schwarz criterion } & 795.8926 & & \multicolumn{2}{|c|}{ Hannan - Quinn criterion } & 784.1607 \\
\hline
\end{tabular}

Note: * the coefficient is statistically significance at 0.1 level, $* *$ at 0.05 , and $* * *$ at 0.01 level

Source: own calculations in SW Gretl

Table 1: Results of the ordered logit model.

stated that the attention of the readers is limited. Because the algorithm of the reach calculation is unknown, it is not possible to determine the exact reason. A detailed content analysis is needed. In our case longer posts were related to the flood situation in Prague in June. Some students had to go to school to pass the state bachelor or master exams. Therefore, the information about the situation (transport possibilities, exam schedule etc.) were for the readers so important that they paid more attention to them (commented them or shared them). Hence, the reach was higher. This is in line with the finding of Yoshimura (2006) that in case of longer tests "adults tend to prioritize meaning over language form". We may conclude that despite that shorter posts are preferred, longer posts can be used in extraordinary situations without worrying about the decrease of the post reach.

2. The company should utilize amusing and creative approaches in social media to better achieve set objectives

Unlike traditional media, social networks comprise various types of media - written, photos or videos. Hence, another question is related to the post content. The company should utilize amusing and creative approaches to better achieve objectives. We tested what type of publication had the highest reach. There were 363 posts, photos, links, shares or videos published at the Facebook pages in 2013. The majority were photos (131), than links (106). There were only 86 original posts created. Two photos, one link and one share were financially supported, in other cases only organic reach can be considered. In absolute terms, the highest reach had photos (374 721), while the posts were seen by 365917 users. On the other hand, the average reach was higher in case of posts (5 082), while photos were surprisingly not that successful (3071). The average reach of photos was even lower when we considered organic reach (not paid) only.

However, we have to account for extremes (more than 3 standard deviations from an average). There were extreme values of reach recorded in June. This was due to the crisis situation (floods in Prague), when the communication from the side of users and administrators was more intense and frequent. Another surpassing situation was in September at the beginning of the academic year during timetable assignment. Also the last post of the year should not be included into analysis as it was paid. The results are displayed in Table 2.

\begin{tabular}{|l|c|c|c|}
\hline & Nr. of posts & Organic reach & Average reach \\
\hline Post & 72 & 5032.2778 & 5082.1806 \\
\hline Photo & 119 & 2746.6639 & 2907.0672 \\
\hline Link & 93 & 2608.6774 & 2864.8602 \\
\hline Share & 35 & 3028.8571 & 3206.9714 \\
\hline Video & 2 & 3301.0000 & 3328.5000 \\
\hline Total & 321 & 3253.5701 & 3418.0405 \\
\hline
\end{tabular}

Source: own calculations

Table 2. Reach of the posts without 12/2013 and extremes.

We find that the average reach was the highest in case of the text posts. This is not in line with results of Hofmann et al. (2013). They examined the communication of local governments on the social network sites and measured the success of the communication in terms of the frequency and polarity of citizens' comments on government posts. They concluded that, in particular, multimedia features like photos and videos contribute to the success of communication" (Hofmann et al., 2013). This is for obvious reason - as Pereira et al. (2014) stated - the Facebook users cannot 
keep up with everything. Their qualitative research (interviews in focus group) revealed that "some content such as videos, fun posts, and events attract attention and stand out from the 'noise'.

Our contradictory results would require detailed examination of the causes. One of them could be the motivation of the Facebook's users. Smock et al. (2011) suggested in their study that ,measuring overall social media use instead of specific feature use obfuscates granular patterns regarding use: who is using what tool to what end". It is possible that for university students are more relevant the text posts with information value (e. g. exam dates) that mere illustrative photos or leaflets. Other possibility is that there were too many photos in comparison with other post types. They were published too often and students stopped to pay attention to them.

In general it might be assumed that the attention of the users slacken when there are too many posts. Therefore, we further examine the number of posts in relation to the reach. The highest total reach was in June, but on average (recalculated at one post) the highest reach was in August. There were only 11 posts published, but they were seen by 67654 users. There were 41 posts (mainly photos - 21), but the total reach (88 725) per one was not that remarkable. One post was seen (on average by 3636 fans). 25\% of the posts had less than 2120 views, which points out on the fact that few posts were seen by a lot of users. Our findings imply that the less number of posts per time period, the higher is their reach. Or in other words publishing too much does not necessary mean that the statuses will have desirable reach.
For example Parsons (2011) analysed 70 Facebook pages of global companies and found out that they "post on average 24 times within a month which implies that consumers receive a message in their news feeds from companies that they like every few days. Companies need to be conscious of not bombarding users with messages." More precisely, it matters to publish the "right" (i.e. relevant) things and the "right" (not too much, not too few) number of them per time period.

\section{The company should utilize applications, games or other elements of virtual reality to increase the involvement of their fans}

The amusing content can be an application, game serving for the purpose of the competition. We analysed the data from Christmas competition which took place in December 2013. Its principle was easy - "open windows" in virtual Advent calendar. After opening (by click) one window another could have been open up to 5 hours. This competition sought to build loyalty of the users - players. They had less than 24 days to open all windows (so the results could have been announced before the Christmas holiday). The Facebook application attracted 548 users (out of 7392 fans) who could win 165 rewards. The majority of users opened only 1 window and lost the interest in future game. The competition also attracted people even in extraordinary hours (e.g. between 3 and 4 AM where the users were more active than usually). The distribution of the player's activity is displayed at Graph 1.

The loyalty of users - players decreased overtime.

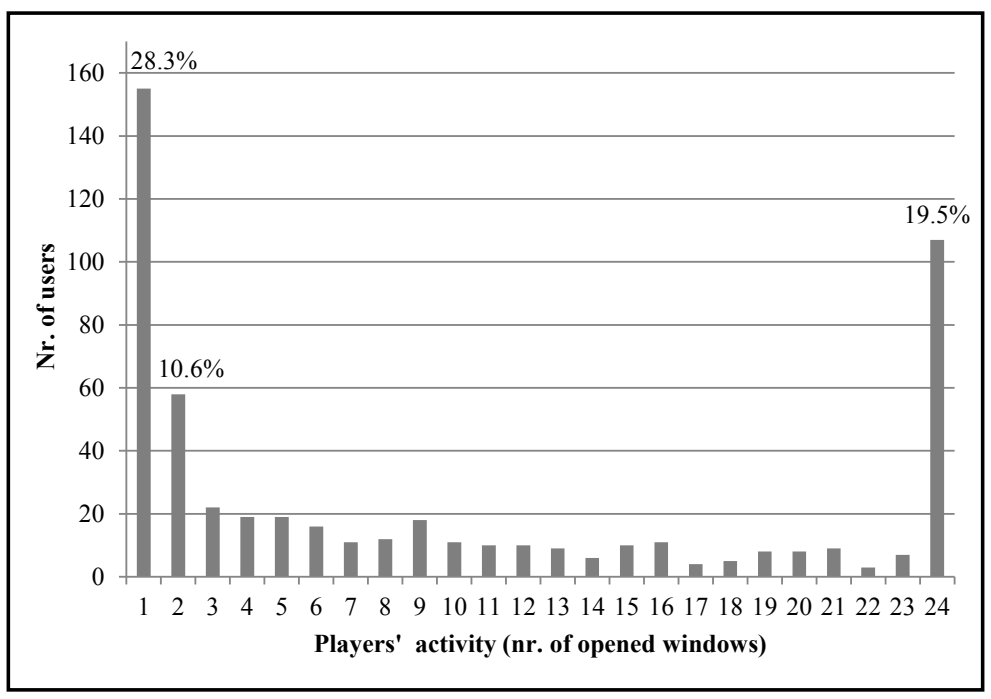

Source: own calculations

Graph 1. Players' activity during competition. 
Half of them opened maximally six windows, three quarters managed maximally 19. But almost $20 \%$ made it to the very end which is quite high conversion number. Therefore, we suggest running competitions with easy rules and longer duration which require longer-term attention of the players to build their loyalty.

The added value of the Christmas competition was that it enabled also personal contact with the users. Won rewards were picked up by the users personally at the university. The organizers had change to talk to users personally and build further relation with them.

An analysis of utilization of the Facebook to promote organic products is done searching for a keyword farmers' market. In general, the number of fans differs according to the localization of farmers market (see Graph 2). The distribution follows "long tail" - one Facebook page had $41 \%$ of all fans, while the share of others is negligible. The survey revealed that Facebook is utilized mainly in big cities by organizers of farmers' market to promote those events. The most fans had non-profit organization "Farmářské trhy" (na Kulat’áku - part of Prague).

There can be found communities, groups (both open and closed) and events related to the farmers market on Facebook. However, the number of likes

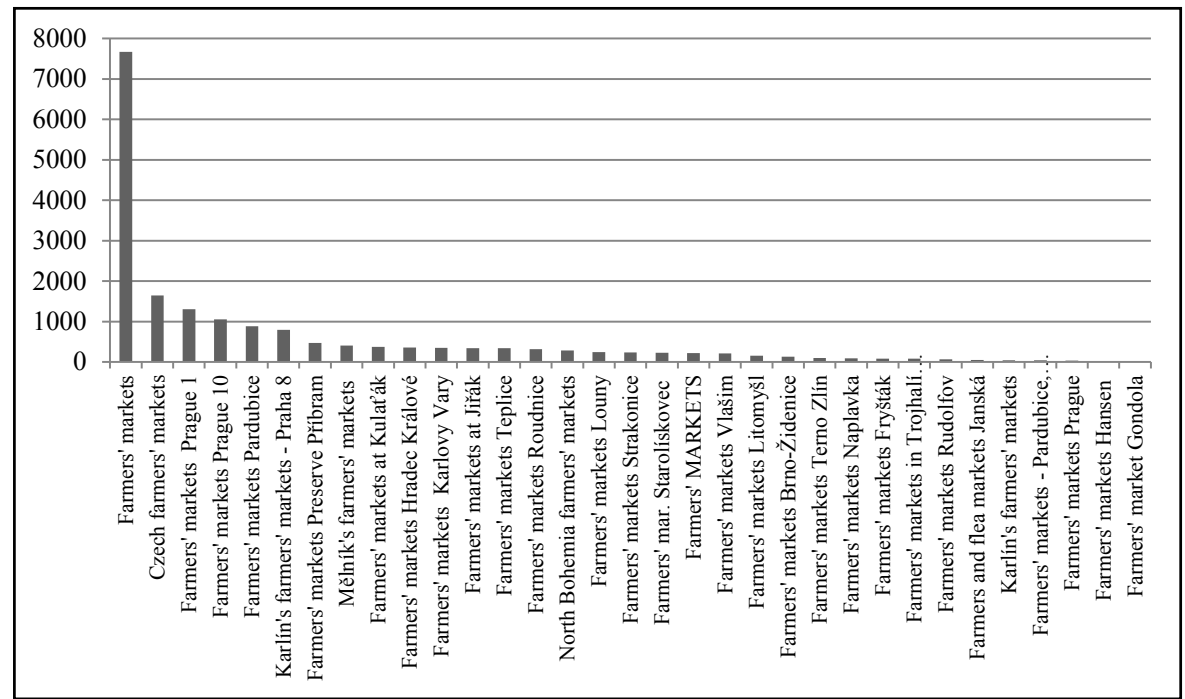

Source: own research at Facebook

Graph 2: The number of fans of Facebook pages - key word: farmers' market.

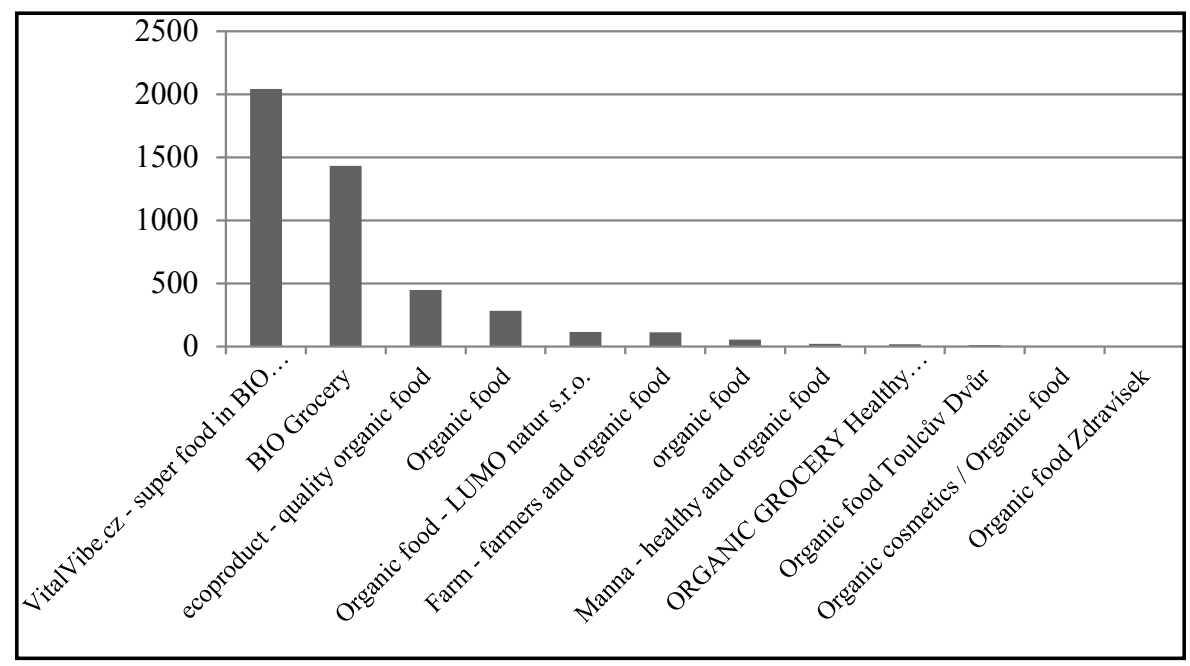

Source: own research at Facebook

Graph 3: The number of fans of Facebook pages - key word: organic products. 
or participation at the events is very modest and imply that Facebook as a marketing tool has its reserves.

Keywords bio products showed only one closed group, one community and one interest. Ecological farming refers only to the study programmes at the Czech University of Life Sciences. Key words organic products revealed few pages of bio products' shops, one community, one place, one group and even one person. (It might be assumed that the shop owner did not know how to create a Facebook page.) Hence, we may conclude that the Facebook is not fully utilize (or even appropriately utilized) for marketing purposes. The distribution of pages' fans can be seen at Graph 3 .

\section{Conclusion}

The aim of the article was to introduce new social media as effective marketing tool for the organic farmers and producers. We presented and verified three suggestions of the Social Media in Business methodology proposed by Lohr (2013) on the data of already successfully working conception of FEM CULS for the time period of 1-11/2013. First suggestion that text of the messages for publication in social media should be short was not proved by our data. Content of the posts revealed that the longest were posted during floods in Prague in June. It is supposed the same effect can be reached during any crisis communication - at the field of the organic farmers it can be any type of quality crisis, such as plant diseases or communication hoaxes. We may conclude that despite that shorter posts are preferred to achieve higher reach, longer posts have its justification in extraordinary situations and their length does not imply the decrease of the post reach.

The statement that the company should utilize amusing and creative approaches in social media to better achieve set objectives was verified on the various types of media's reach (text post, photos, links, shares and videos). Our data revealed contradictory results. The highest reach had text posts (probably connected with higher information value for the students). Another reason might be that there were too many photos published at once. It is efficient to use a balanced mix of media formats. For organic farmers it can be used for educative purposes and also for brand building. Therefore, in conjunction with our data based research, we suggest publishing the relevant content in reasonable time period (not more than one post per day on average).
Third suggestion that the company should utilize applications, games or other elements of virtual reality to increase the involvement of their fans was verified on the Christmas competition. The data showed that game (Facebook application) with easy rules and longer duration attracted considerable number of fans from which one fifth completed the game. For that reason, we recommend to the organic farmers or producers holding the competitions to build users loyalty.

The researched in the area of utilization of Facebook to promote organic products showed that this social medium is still not fully utilized yet. The distribution of the fans of Facebook pages follows "long tail" - one Facebook page promoting organic markets had $41 \%$ of all fans, while the share of the other pages was negligible. This implies using the theory of social capital exchange according to Emerson (2003) that the potential of social media for farmers' pages is nowadays still high and still waits for its utilization. This might be due to various reasons such as availability of the (broadband) internet connection, age structure of the internet users and farmers, or the lack of knowledge about the possibilities and social media communication skills. We showed that social media are a promising tool which can be used by organic farmers to promote their products.

Today, with the last changes of Facebook rules applied, it is now allowed to hold competitions out of the separated Facebook applications and organic farmers with not enough budgets are able to organize those activities directly on Facebook page timeline. This can lead to increasing of popularity and activity on Facebook page and it can produce higher post reach and brand building effect. As we showed in our article, the methods of using of social media are developed and organic farmers should exploit them.

A challenge for future research is to perform detailed content analysis of the posts in relation to their reach. This will shed better light on more effective social media usage by the organic farmers or producers.

\section{Acknowledgements}

The knowledge and data presented in the present paper were obtained as a result of the Grant No. 20151053 of the FEM CULS Prague Internal Grant Agency titled ,Development and use of information and communication technologies in rural regions“. 
Corresponding author:

Ing. Marie Pechrová

Department of Economics, Faculty of Economics and Management,

Czech University of Life Sciences Prague, Kamýcká 129, Praha 6-Suchdol, 16521, Czech Republic

E-mail: pechrova@pef.czu.cz

\section{References}

[1] Berthon R., P., Pitt, L. F, Plangger, K., Shapiro, D. Marketing meets Web2.0, social media, and creative consumers: Implications for international marketing strategy. Business Horizons. 2012, Vol. 55, p. 261 - 271. ISSN 0007-6813.

[2] Emerson, R. M. Social Exchange Theory. Annual Review of Sociology. 2003, Vol. 11, No. 2, p. 335 - 362. ISSN 0360-0572.

[3] Gregurec, I., Vranesevic, T., \& Dobrinic, D. The importance of database marketing in social network marketing. International Journal of Management Cases. 2011, Vol. 13, No. 4, p. 165 - 172. ISSN 1741-6264.

[4] Hofmann, S., Beverungen, D., Räckers, M., Becker, J. What makes local governments' online communications successful? Insights from a multi-method analysis of Facebook. Government Information Quarterly. 2013, Vol. 30, No. 6, p. 387 - 396. ISSN 0747-5632.

[5] Jensen, A. N., Baggesen, D. L. Global Safety of Fresh Produce: 2 - Niche farm fresh products. Elsevier B.V.: 2014, p. 9 - 21. ISBN 978-1-78242-018-7. DOI: 10.1533/9781782420279.1.9.

[6] Kánská, E., Jarolímek, J., Hlavsa, T., Šimek, P., Vaněk, J., Vogeltanzová, T. Using social networks as an integration tool in rural areas of the Czech Republic - agricultural enterprises. ACTA Universitatis Agriculturae et Silviculturae Mendelianae Brunensis. Vol. 60, 2012, issue 4, p. 173 - 180. ISSN 1211-8516.

[7] Lohr, V. Technologie Web 2.0 a management jejich implementace. [disertation thesis]. Czech University of Life Sciences Prague: Prague, 2013.

[8] Michaelidou, N. Siamagka, N. T., Christodoulides, G. Usage, barriers and measurement of social media marketing: An exploratory investigation of small and medium B2B brands. Industrial Marketing Management. 2011, Vol. 40, No. 7, p. 1153 - 1159. ISSN 0019-8501.

[9] Parsons, A. L., Social Media from a Corporate Perspective: A Content Analysis of Official Facebook Pages. Proceedings of the Academy of Marketing Studies. 2011, Vol. 16, No. 2, p. $11-45$. ISBN 2150-5187.

[10] Peters, K., Chen, Y., Kaplan, A. M., Ognibeni, B., Pauwels, K. Social Media Metrics - A Framework and Guidelines for Managing. Journal of Interactive Marketing. 2013, Vol. 27, No. 4, p. 281 - 298. ISSN 1094-9968.

[11] Pereira, H. G., de Fátima Salgueiro, M., Mateus, I. Say yes to Facebook and get your customers involved! Relationships in a world of social networks. Business Horizon, 2014, in Press - Corrected Proof, 8 p. ISSN 0007-6813.

[12] Rapp, A., Skinner Beitelspacher, L., Grewal, D., Hughes, D. E. Understanding social media effects across seller, retailer, and consumer interactions. Journal of the Academy of Marketing Science. 2013, Vol. 41, No. 5, p. 547 - 566. ISSN 0092-0703.

[13] Sage, J. L., Goldberger, J. R. Decisions to direct market: Geographic influences on conventions in organic production. Applied Geography, May 2012, Vol. 34, p. 57 - 65. ISBN 0950-3293. DOI: 10.1016/j.apgeog.2011.10.014

[14] Smock, A. D., Ellison, N. B., Lampe, C., Wohn Y. D. Facebook as a toolkit: A uses and gratification approach to unbundling feature use. Computers in Human Behavior. 2011, Vol. 27, p. 2322 - 2329. ISSN $0747-5632$. 
[15] Sturiale L., Scuderi, A. Evaluation of Social Media Actions for the Agrifood System. Procedia Technology. 2013, No. 8, p. 200 - 208. ISSN 2212-0173.

[16] Yoshimura F. Does manipulating foreknowledge of output tasks lead to differences in reading behaviour, text comprehension and noticing of language form? Language Teaching Research 2006, 10, 4, p. 419 - 434. ISSN 1477-0954. DOI: 10.1191/13621688061r204oa. 